\title{
Specialized Transduction of a Cysteine Marker by Rhizobium meliloti Phage 16-3
}

\author{
By ZÓRA SVÁB, ÁDÁM KONDOROSI AND LÁSZLÓ OROSZ* \\ Institute of Genetics, Biological Research Center, Hungarian Academy of Sciences, \\ H-6701 Szeged, P.O. Box 521, Hungary
}

(Received 1 December 1977; revised 6 February 1978)

\begin{abstract}
Specialized transduction by phage 16-3 of one of the cys markers of Rhizobium meliloti is described. The frequency of transduction was $10^{-6}$ to $10^{-7}$ per plaque-forming unit. About two-thirds of the transductants were heterogenotes, unstable for the cys ${ }^{+}$marker, and yielded high frequency transducing lysates $\left(10^{-2}\right.$ per plaque-forming unit). In phage lysates, plaque-forming transducing particles were directly demonstrated while non-plaqueforming particles were only detected indirectly via complementation of defective lysogenic transductants. In the defective transductants, the two distal ends of the vegetative phage map were lacking. By plasmid transfer, the attachment site of phage 16-3 was located close to the cys-46 and met-5 markers. Transduction of the met-5 marker could not be demonstrated.
\end{abstract}

\section{INTRODUCTION}

Fixation of atmospheric nitrogen in symbiotic association of legumes and Rhizobium species has recently attracted much interest. The genetics of Rhizobium is much less developed than the genetics of Escherichia coli or Bacillus subtilis, partly because of the limited possibilities for genetic transfer. Transformation (Balassa, 1963), generalized transduction (Kowalski, 1967) and, recently, chromosome mobilization mediated by plasmids (Beringer \& Hopwood, 1976; Meade \& Signer, 1977; Kondorosi et al., 1977b) have been reported as possible methods for the genetic analysis of Rhizobium.

In this paper specialized transduction with phage 16-3 (Szende \& Ördögh, 1960; Orosz et al., 1973) of Rhizobium meliloti 41 is described. Some of the results have been discussed previously (Sik \& Orosz, 1971; Sváb et al., 1973).

\section{METHODS}

Bacteria. The wild-type strain was Rhizobium meliloti 41 . The auxotrophic mutants used were: A1 his-1 (Orosz \& Sik, 1970), F46 cys-46 (Kondorosi et al., 1974), AK178 cys-46 met-5 str-3 and AK180 cys-46 ade-3 $s t r-3$ (Kondorosi et al., 1977 b). Strain F46 is probably a sulphite reductase mutant, since it grows on minimal medium supplemented with cysteine, cystine or $\mathrm{Na}_{2} \mathrm{~S}$ but not with $\mathrm{MgSO}_{4}, \mathrm{Na}_{2} \mathrm{SO}_{3}$ and homocysteine. Strains NG10 cys-10, K7 arg-7 and K3 trp-3 were obtained by treatment of $R$. meliloti 41 with $N$-methyl- $N^{\prime}-$ nitro- $N$-nitrosoguanidine (Kondorosi et al., 1973). Reversion rates of the mutants were $10^{-7}$ to $10^{-8}$.

Bacteriophages. Wild-type phage 16-3 (Szende \& Ördögh, 1960), its thermoinducible (ti3, ti4, ti5) mutants in the immunity gene $c$, and thermosensitive $(t s 5124, t s 216, t s 5116, t s 518, t s 5218, t s 5222, t s 2, t s 5)$ and lysisdeficient (L5I) derivatives (Orosz et al., 1973) were used.

Plasmid. Plasmid R68.45 was kindly provided by Professor B. W. Holloway.

Media. Yeast tryptone medium (YTB) contained (per litre): tryptone (Oxoid), 10 g; yeast extract (Oxoid), $1 \mathrm{~g} ; \mathrm{NaCl}, 5 \mathrm{~g} ; \mathrm{CaCl}_{2}, 1 \mathrm{mmol} ; \mathrm{MgCl}_{2}, 1 \mathrm{mmol}$. Glucose ammonia minimal medium (BRP) contained (per litre) $\mathrm{NaCl}, 1 \mathrm{~g} ; \mathrm{NH}_{4} \mathrm{Cl}, 3 \mathrm{~g}$; glucose, $2 \mathrm{~g} ; \mathrm{KH}_{2} \mathrm{PO}_{4}, 0.7 \mathrm{~g}$; Tris, $3 \mathrm{~g} ; \mathrm{HCl}, 0.02 \mathrm{~mol}$; biotin, $10 \mu \mathrm{g}$. The $\mathrm{pH}$ of the media was adjusted to 7.0 with $\mathrm{NaOH}$ (Orosz \& Sik, 1970). For testing transductant colonies,

* Present address: Department of Genetics, Attila József University, H-6726 Szeged, Középfasor 52, Hungary. 
BRP was solidified with $1.5 \%(\mathrm{w} / \mathrm{v})$ agar (Difco Noble). Glucose succinate ammonia minimal medium (GTPS), described by Kondorosi et al. (1977a), was modified by the addition of $\mathrm{NH}_{4} \mathrm{Cl}\left(1 \mathrm{~g} \mathrm{l}^{-1}\right)$.

Ultraviolet (u.v.) irradiation. Samples $(2 \mathrm{ml})$ of bacteria or phage were suspended in saline plus $10 \mathrm{~mm}$ $\mathrm{CaCl}_{2}$ in Petri dishes and irradiated with a $30 \mathrm{~W}$ Philips germicidal lamp at a distance of $90 \mathrm{~cm}$.

Preparation of phage lysate. Lysogenic bacteria or bacteria infected by phage at a multiplicity of infection of 5 were grown to $2 \times 10^{9}$ to $4 \times 10^{9}$ bacteria $\mathrm{ml}^{-1}$ at $28^{\circ} \mathrm{C}$ in YTB broth supplemented with $10 \mathrm{mM}-\mathrm{CaCl}_{2}$. The cultures were diluted twofold with the same medium and then either phage multiplication was induced or induction was omitted. For induction, $t i$ lysogens were incubated for $40 \mathrm{~min}$ at $36^{\circ} \mathrm{C}$ and $\mathrm{c}^{+}$lysogens were u.v. irradiated for $10 \mathrm{~s}$. After an additional $3 \mathrm{~h}$ growth period at $28{ }^{\circ} \mathrm{C}$, Hyflo super cell $\left(0.2 \mathrm{~g} \mathrm{ml}^{-1}\right.$; Reanal Chemical Co., Budapest, Hungary) was added, and $15 \mathrm{~min}$ later the bacterial debris was sedimented by centrifugation. Chloroform-treated supernatant was used as the phage lysate. The lysate had a titre of about $10^{11}$ plaque-forming units (p.f.u.) $\mathrm{ml}^{-1}$ when prepared from infected bacteria with or without induction, or from induced lysegenic bacteria. The titre of lysates from uninduced lysogenic bacteria was about 100-fold lower. Phage lysates were prepared from cultures set up from transductants and from turbid plaques as described for lysogenic bacteria.

Transduction technique. Recipient bacteria grown to $2 \times 10^{9}$ to $4 \times 10^{9}$ bacteria $\mathrm{ml}^{-1}$ in YTB broth were diluted two- to threefold with YTB broth, and then the $\mathrm{CaCl}_{2}$ concentration of the culture was raised to $10 \mathrm{~mm}$. After $2 \mathrm{~h}$ further incubation, $0.9 \mathrm{ml}$ of the culture was mixed with $0.1 \mathrm{ml}$ phage lysate. After $30 \mathrm{~min}$, $0.05 \mathrm{ml}$ of the mixture was spread on to BRP agar plates and incubated for 3 to $5 \mathrm{~d}$. All incubations were carried out at $28^{\circ} \mathrm{C}$.

Phage neutralization. Phage 16-3 rabbit antiserum (Orosz et al., 1973) was used.

Bacterial mating. Donors and recipients grown overnight in YTB broth at $28^{\circ} \mathrm{C}$ with aeration were mixed in a ratio of $1: 1$ and plated out on YTB agar. After incubation for $24 \mathrm{~h}$ at $28^{\circ} \mathrm{C}$, the bacteria were scraped off the surface of the plates, suspended in phosphate-buffer $(0.02 \mathrm{M} ; \mathrm{pH} 7.4)$ containing $0.9 \%(\mathrm{w} / \mathrm{v}) \mathrm{NaCl}$ and plated on selective media. Selective media were based on GTPS medium and supplemented, as required, with amino acids $\left(50 \mu \mathrm{g} \mathrm{ml}^{-1}\right)$ adenine $\left(25 \mu \mathrm{g} \mathrm{ml}^{-1}\right)$ and streptomycin $\left(100 \mu \mathrm{g} \mathrm{ml}^{-1}\right)$. Recombinants appeared after $48 \mathrm{~h}$ incubation at $28^{\circ} \mathrm{C}$ (Kondorosi et al., 1977 b).

\section{RESULTS}

Infection of the cysteine auxotroph strain F46 (cys-46) with lysates of phage 16-3 led to the appearance of prototrophic colonies at a frequency of $10^{-7}$ to $2 \times 10^{-6}$ per p.f.u. Treatment of the lysates with serum prepared against phage 16-3 destroyed the effect but treatment with DNAase had no effect, suggesting this phenomenon to be a transduction. Transducing activity of the lysates was not dependent on the phage mutants used $\left(c^{+}, t i, t s\right)$ or on the nature of prophage induction (spontaneous lysis, u.v. or thermoinduction). Attempts to transduce several other markers, namely cys-10, his-1, arg-7, trp-3, met-5 and ade-3, were unsuccessful. Conjugational mapping data (unpublished results) has indicated that cys-10 and cys- 46 are about one-third of the Rhizobium chromosome apart.

\section{Properties of $\mathrm{Cys}^{+}$transductants}

The $\mathrm{Cys}^{+}$colonies (transductants) obtained were individually tested for the ability to give rise to lysates with high frequency transducing (HFT) activity. Of the lysates from 145 clones tested, 102 transduced the cys-46 marker at high frequency $\left(5 \times 10^{-2}\right.$ to $10^{-2}$ per p.f.u.) while $43 \mathrm{had}$ low frequency transducing (LFT) activity $\left(10^{-6}\right.$ to $10^{-7}$ per p.f.u.). Transductants giving HFT lysates segregated Cys ${ }^{-}$colonies during growth at a wide range of frequencies, indicative of heterogenotes. In contrast those which liberated LFT lysates were stable $\mathrm{Cys}^{+}$and presumably haploid recombinants. Some properties of the transductants are summarized in Table 1.

\section{Effect of phage multiplicity on transduction}

A randomly chosen HFT lysate was used for transduction at different multiplicities (Fig. 1). The number of transductants increased linearly with the number of infecting phage, up to a multiplicity of infection (m.o.i.) of 5 to 10. The slope of the curve is consistent with the formation of transductants by one-hit, helper-independent events. 


\section{Table 1. Properties of transductants}

Transduction was performed using phage lysates at an m.o.i. of 5 to 10. Phage lysates obtained from 145 transductant colonies were prepared either by thermoinduction (ti4 and ti5) or without any induction (16-3). For the segregation test, transductant colonies were purified by re-streaking on BRP agar. One clone of each transductant was grown in YTB broth to $10^{9}$ bacteria $\mathrm{ml}^{-1}$ and spread on to YTB agar to form 100 to 200 colonies per plate. After $40 \mathrm{~h}$ incubation, colonies were replica-plated on to BRP and YTB agar.

\begin{tabular}{|c|c|c|c|c|c|}
\hline \multirow{2}{*}{$\begin{array}{l}\text { Phage } \\
\text { lysate }\end{array}$} & \multirow{2}{*}{$\begin{array}{l}\text { No. of Cys } \\
\text { colonies } \\
\text { tested }\end{array}$} & \multicolumn{2}{|c|}{$\begin{array}{c}\text { No. of colonies } \\
\text { producing } \\
\text { lysates } \\
\text { of type: }\end{array}$} & \multirow{2}{*}{$\begin{array}{l}\text { No. of } \\
\text { unstable } \\
\text { clones } \\
\text { per total } \\
\text { examined }\end{array}$} & \multirow{2}{*}{$\begin{array}{c}\text { Percentage of Cys } \\
\text { progeny in } \\
\text { unstable clones }\end{array}$} \\
\hline & & HFT & LFT & & \\
\hline $16-3$ & 34 & 20 & 14 & $\begin{array}{l}5 / 5 \\
0 / 2\end{array}$ & $1 \cdot 5,42,34,52,65$ \\
\hline ti4 & 34 & 28 & 6 & $\begin{array}{l}3 / 3 \\
0 / 2\end{array}$ & $18,20,31$ \\
\hline$t i 5$ & 77 & 54 & 23 & $\begin{array}{l}5 / 5 \\
0 / 4\end{array}$ & $22,41,46,54,81$ \\
\hline Total & 145 & 102 & 43 & $\begin{array}{c}13 / 13 \\
0 / 8\end{array}$ & \\
\hline
\end{tabular}

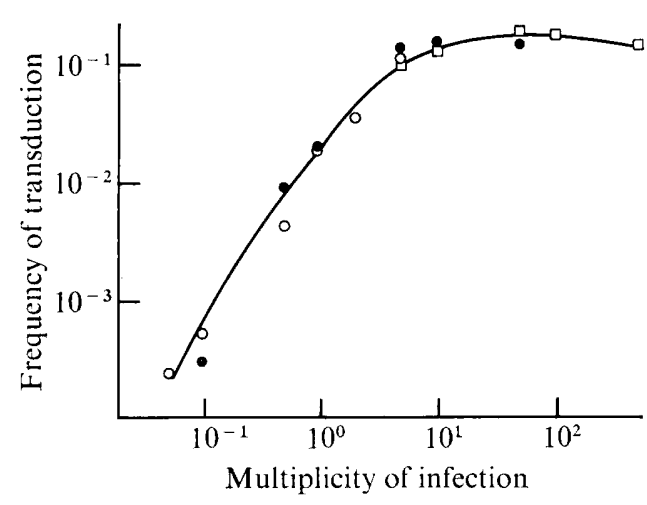

Fig. 1

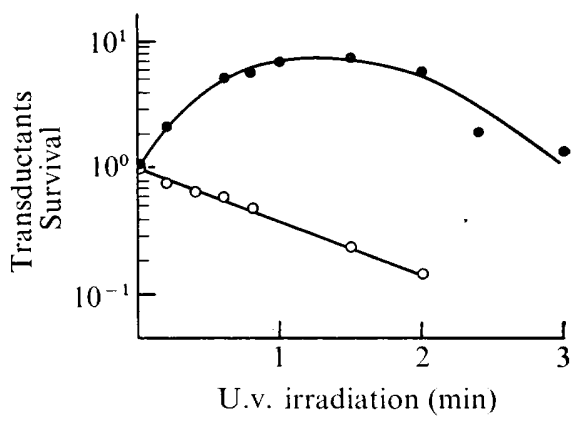

Fig. 2

Fig. 1. Effect of multiplicity of infection on transductant formation. Cultures of $\mathrm{F} 46$ grown overnight in YTB broth were diluted with YTB plus $10 \mathrm{mM}^{-C_{a C l}}$ to concentrations of $1.0 \times 10^{9}(O)$, $1.0 \times 10^{8}(O)$ and $1.0 \times 10^{7}(\square)$ bacteria $\mathrm{ml}^{-1}$, and used as recipients. Samples $(0.9 \mathrm{ml})$ of each culture were mixed with $0.1 \mathrm{ml}$ of HFT ti3 lysates of different dilutions. After 30 min aeration, samples were spread on to BRP plates where transductants appeared after 3 to $4 \mathrm{~d}$ incubation at $28^{\circ} \mathrm{C}$.

Fig. 2. Effect of u.v. light on viability and transducing activity of phage 16-3. HFT ti3 lysate was irradiated by u.v. light for different periods. Transduction was carried out with these lysates as described in Methods. Ratios of transducing activity (O) and of plaque formation (O) of the irradiated sample to that of an unirradiated sample.

U.v. irradiation of an HFT lysate resulted in an exponential decrease in p.f.u. At low doses the transducing activity increased while at high doses it declined (Fig. 2). The increase has been attributed to an increase in the frequency of recombination between the host chromosome and the exogenote (Arber, 1958).

\section{Nature of the transducing particles}

To investigate whether the $c y s^{+}$transducing particles were defective $(d c)$ or plaque-forming $(p c)$, six HFT lysates derived from independent transductants were plated out to form 
Table 2. Frequency of $16-3 p c$ particles

HFT lysates were allowed to form plaques on F46 indicator bacteria on YTB agar by the agarlayer method. After $2 \mathrm{~d}$ incubation, the turbid centres of the plaques were spread with toothpicks on to BRP agar. Cys ${ }^{+}$turbid centres formed colonies on BRP agar after incubation for 2 to $5 \mathrm{~d}$ at $28^{\circ} \mathrm{C}$.

HFT lysate

HFT3

HFT109

HFT169

HFT174

HFT179

HFT181
No. of $\mathrm{Cys}^{+}$turbid centres per total tested
$22 / 130$
$0 / 147$
$0 / 81$
$0 / 45$
$0 / 140$
$0 / 43$

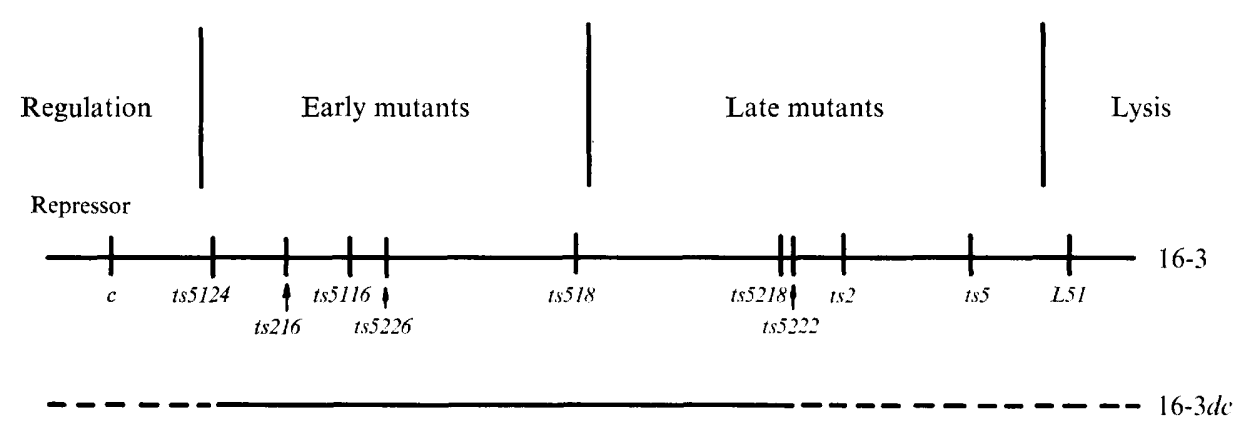

Fig. 3. Map of the $16-3 d c$ defective prophage. Solid lines represent regions present, dashed lines indicate regions deleted. (Map of 16-3 from Orosz et al., 1973.)

plaques on the cys indicator strain F46 on YTB agar. After $2 \mathrm{~d}$, bacteria growing in the turbid centres of the plaques were spread with toothpicks on BRP agar for testing prototrophic growth (Table 2). Only one of the six HFT lysates gave Cys ${ }^{+}$bacteria. This lysate, HFT3, evidently contained phage particles able both to produce plaques and to transduce the cysteine marker $(16-3 p c)$. Phage lysates were prepared from the turbid centres of 27 plaques of the HFT3 lysate, and transductions were performed at a m.o.i. of $0 \cdot 1$. Of the 27 lysates, 21 had HFT activity $\left(5 \times 10^{-1}\right.$ to 1 per p.f.u.).

With the other five HFT lysates, no prototrophic bacteria were detected in the turbid centres of the plaques. Since the initial lysates had HFT activity, transducing and plaqueforming abilities were probably unlinked, so the phage population in these lysates consisted of separate defective transducing and plaque-forming particles. If this is correct, then defective lysogens should be found among transductants. To test this, transductions were carried out at a low m.o.i. $(0 \cdot 1$ to $0 \cdot 5)$ to avoid multiple infection and subsequent tandem lysogenization. Five $\mathrm{Cys}^{+}$clones were isolated and studied further. None of the five clones liberated viable phages and all were sensitive to superinfection. We looked for defective phages in these transductants by complementation tests using a series of temperaturesensitive $(t s)$ phage mutants with known map positions. Complementation analysis showed that the five transductant clones were defective lysogens. All of them contained genes from the middle part but not the two ends of the 16-3 vegetative chromosome (Table 3 , Fig. 3). The five defective lysogens were superinfected with viable phages in an attempt to produce HFT lysates. Unexpectedly, the lysates had no HFT activity. Furthermore, the $\mathrm{Cys}^{+}$phenotype of the transductants was stable, since no $\mathrm{Cys}^{-}$segregants were found among 200 progeny tested from each of the five transductants. 
Table 3. Marker rescue in transductants unable to release viable phage particles upon induction

Transductant clones were grown in YTB broth to $5 \times 10^{9}$ bacteria $\mathrm{ml}^{-1}$ and plated by the standard agar-layer method on YTB agar. After $1 \mathrm{~h}$, lysates of different phages $\left(0.02 \mathrm{ml} ; 10^{5}\right.$ and $10^{7}$ p.f.u. $\mathrm{ml}^{-1}$ ) were dropped on to the plates. Lysis (complementation) was scored after $24 \mathrm{~h}$ at both 28 and $36^{\circ} \mathrm{C}$.

\begin{tabular}{|c|c|c|c|c|c|c|}
\hline \multirow{2}{*}{$\begin{array}{l}\text { Phage stock } \\
\text { used for } \\
\text { superinfection }\end{array}$} & \multirow[b]{2}{*}{$\begin{array}{c}\text { Temp. } \\
\left({ }^{\circ} \mathrm{C}\right)\end{array}$} & \multicolumn{5}{|c|}{ Cys $^{+}$clone and phage lysate used to produce it } \\
\hline & & $\begin{array}{c}\text { D61 } \\
\text { LFT } t s 5116\end{array}$ & $\begin{array}{c}\text { D45 } \\
\text { LFT } t s 5124\end{array}$ & $\begin{array}{c}\text { D33 } \\
\text { HFT } t i 3\end{array}$ & $\begin{array}{c}\text { D42 } \\
\text { HFT } t i 4\end{array}$ & $\begin{array}{c}\text { D55 } \\
\text { HFT } t i 5\end{array}$ \\
\hline Wild-type* & $\begin{array}{l}28 \\
36\end{array}$ & $\begin{array}{l}+ \\
+\end{array}$ & $\begin{array}{l}+ \\
+\end{array}$ & $\begin{array}{l}+ \\
+\end{array}$ & $\begin{array}{l}+ \\
+\end{array}$ & $\begin{array}{l}+ \\
+\end{array}$ \\
\hline$t s 5124$ & $\begin{array}{l}28 \\
36\end{array}$ & $\begin{array}{l}+ \\
+\end{array}$ & $\begin{array}{l}+ \\
-\end{array}$ & + & $\stackrel{+}{-}$ & \pm \\
\hline$t s 216$ & $\begin{array}{l}28 \\
36\end{array}$ & $\begin{array}{l}+ \\
+\end{array}$ & $\begin{array}{l}+ \\
+\end{array}$ & $\begin{array}{l}+ \\
+\end{array}$ & $\begin{array}{l}+ \\
+\end{array}$ & $\begin{array}{l}+ \\
+\end{array}$ \\
\hline$t s 5116$ & $\begin{array}{l}28 \\
36\end{array}$ & $\begin{array}{l}+ \\
-\end{array}$ & $\begin{array}{l}+ \\
+\end{array}$ & $\begin{array}{l}+ \\
+\end{array}$ & $\begin{array}{l}+ \\
+\end{array}$ & $\begin{array}{l}+ \\
+\end{array}$ \\
\hline$t s 518$ & $\begin{array}{l}28 \\
36\end{array}$ & $\begin{array}{l}+ \\
+\end{array}$ & $\begin{array}{l}+ \\
+\end{array}$ & $\begin{array}{l}+ \\
+\end{array}$ & $\begin{array}{l}+ \\
+\end{array}$ & + \\
\hline$t s 5218$ & $\begin{array}{l}28 \\
36\end{array}$ & $\begin{array}{l}\text { NT } \\
\text { NT }\end{array}$ & $\begin{array}{l}\text { NT } \\
\text { NT }\end{array}$ & $\begin{array}{l}+ \\
+\end{array}$ & $\begin{array}{l}+ \\
+\end{array}$ & $\begin{array}{l}+ \\
+\end{array}$ \\
\hline$t s 5222$ & $\begin{array}{l}28 \\
36\end{array}$ & $\stackrel{+}{-}$ & $\begin{array}{l}+ \\
-\end{array}$ & $\begin{array}{l}\text { NT } \\
\text { NT }\end{array}$ & $\begin{array}{l}\text { NT } \\
\text { NT }\end{array}$ & $\begin{array}{l}\text { NT } \\
\text { NT }\end{array}$ \\
\hline$t s 2$ & $\begin{array}{l}28 \\
36\end{array}$ & \pm & \pm & \pm & $\begin{array}{l}+ \\
-\end{array}$ & $\stackrel{+}{-}$ \\
\hline$t s 5$ & $\begin{array}{l}28 \\
36\end{array}$ & $\begin{array}{l}+ \\
-\end{array}$ & $\begin{array}{l}\text { NT } \\
\text { NT }\end{array}$ & $\begin{array}{l}+ \\
-\end{array}$ & $\stackrel{+}{-}$ & + \\
\hline L5I & 28 & - & NT & NT & NT & NT \\
\hline
\end{tabular}

+ , Lysis; - , no lysis; NT, not tested.

* Cys ${ }^{+}$transductants are sensitive to superinfection which indicates the loss of $c^{+}$function.

Table 4. Mapping of the att 16-3 region on the Rhizobium chromosome

Agar surface matings were performed as described in Methods. Counter selection for the donor was by streptomycin resistance. The frequency of transfer of the plasmid was about $3 \times 10^{-1}$. Recombinant colonies were purified by streaking for single colonies on selective media before testing for phage production as an unselected marker. Purified colonies were individually tested on indicator bacteria at $36^{\circ} \mathrm{C}$ where $c^{+}$phage produced turbid plaques and $t i 3$ phage produced clear plaques.

\begin{tabular}{|c|c|c|c|}
\hline Donor & Recipient & $\begin{array}{l}\text { Selected } \\
\text { markers }\end{array}$ & $\begin{array}{c}\text { Coinheritance of } \\
\text { unselected }(t i 3) \text { marker }\end{array}$ \\
\hline R. meliloti 41(ti3) (R68.45) & AK $178\left(c^{+} c y s-46\right.$ met -5 str -3$)$ & $\begin{array}{l}\mathrm{met}^{+}{ }^{+} y s^{+} \\
\text {met }^{+} \\
\text {met }^{+} c y s \\
\text { cys }^{+}\end{array}$ & $\begin{array}{c}182 / 182 \\
29 / 29 \\
27 / 27 \\
80 / 92\end{array}$ \\
\hline R. meliloti $41($ ti3) (R68.45) & AK $180\left(c^{+}\right.$cys-46 ade- 3 str -3$)$ & $\begin{array}{l}\text { ade } \text { cys }^{+} \\
\text {ade } \\
\text { ade } \\
\text { cys }^{+} \\
\text {cys }^{+} \text {ade }\end{array}$ & $\begin{array}{c}139 / 149 \\
86 / 149 \\
0 / 16 \\
121 / 138 \\
12 / 14\end{array}$ \\
\hline
\end{tabular}

Localization of the att16-3 region on the Rhizobium chromosome by conjugation

The circular linkage map of the $R$. meliloti 41 chromosome was recently established (Kondorosi et al., 1977 b). cys-46 and ade-3 were cotransferred at a frequency of $0 \cdot 57$, and cys-46 and met-5 at a frequency of 0.76 , and the order ade-3 cys-46 met-5 was found. The att16-3 region could therefore be located by determining the coinheritance of the $c$ gene on the prophage with the $c y s-46$, ade- 3 and met-5 markers. 
Plasmid R68.45 was introduced into $R$. meliloti 41 lysogenic for $t i 3$ and was used as a donor in matings with strains AK178 (cys-46 met-5 str-3) and AK180 (cys-46 ade-3 str-3) which were lysogenic for the wild-type phage. With selection for either $\mathrm{met}^{+}$or $\mathrm{met}^{+} \mathrm{cys}^{+}$, all recombinants $(100 \%)$ inherited the ti3 allele. With selection for either $c y s^{+}$or $a d e^{+} c y s^{+}$, however, only about $90 \%$ of the recombinants carried the $t i 3$ allele (Table 4).

\section{DISCUSSION}

Upon lysogenization, the genome of phage 16-3 integrates into the chromosome of $R$. meliloti near one of the cysteine genes, as demonstrated by the specific transduction of the cys-46 marker and confirmed by conjugational data. That this transduction was specialized was established by the lack of transfer of six other auxotrophic markers. Furthermore, some of the $\mathrm{Cys}^{+}$transductants (102 out of 145) were heterogenotes as described for other specialized transducing phages such as $\lambda$ or $\phi 170$ (Morse, Lederberg \& Lederberg, 1956; Iijima, 1966). Heterogenotes yielded HFT lysates. The transducing activity of the 16-3 HFT lysates was $10^{-2}$ per p.f.u. For comparison, the activity of $\lambda$ or $\phi 80$ HFT lysates was $10^{-1}$ per p.f.u. (Morse et al., 1956; Matsushiro, 1963) and that of P22, $\phi 170$ or $\phi 81$ HFT lysates was $10^{-3}$ to $10^{-4}$ per p.f.u. (Smith-Keary, 1966; Iijima, 1966; Takeda, Morishita \& Yura, 1970).

These features suggest that the 16-3-R. meliloti system resembles systems capable only of specialized transduction, for example $\lambda$ in $E$. coli (Morse et al., 1956) and $\phi 80$ in $E$. coli (Matsushiro, 1963), and clearly differs from other systems which are also capable of generalized transduction, for example P22 in Salmonella typhimurium (Smith-Keary, 1966), P1 in E. coli, P1 in Shigella dysenteriae (Luria, Adams \& Ting, 1960) and 34 in Proteus mirabilis (Coetzee, 1974).

There were two types of transducing particles in the 16-3 phage lysates. The presence of plaque-forming $c y s^{+}(16-3 p c)$ transducing particles was confirmed directly. Transducing particles of this type have been described previously, for example $\lambda p b i o, \phi 80 p t$ and $\phi 81 p g$ (Wollman, 1963; Matsushiro, Sato \& Kida, 1964; Takeda et al., 1970). However, formation of defective $c y s^{+}$transducing (16-3dc) particles was detected indirectly. Transductants raised from multiple infection liberated HFT lysates although they did not contain any $p c$ particles. In these lysates, therefore, particles unable to form plaques had to be responsible for transduction. Furthermore, in some of the transductants from single infection, which did not yield any viable phages, phage genes mapping in the middle of the vegetative phage chromosome could be demonstrated by marker rescue (Table 3 ). The terminal ends and the $c$ region coding for superinfection immunity were missing from the defective prophages. Although these transductants contained defective prophages, no HFT lysates could be obtained on superinfection. This is in contrast to all other known defective transducing particles, for example $\lambda d g, \mathrm{P} 1 d l$ and $\phi 80 d t$.

The properties of the 16-3dc particles can best be explained if $d c$ particles can be integrated into, but not excised from the host chromosome. This possibility was supported by the observation that transductants from a single infection did not segregate Cys ${ }^{-}$progeny, and no induction of HFT lysates was possible even on superinfection, although some of the 16-3 genes were still carried by the host chromosome. On the other hand, integration of the 16-3 $d c$ particle and the helper in tandem during multiple infection would make the production of HFT lysates possible, since integrated helper would exert not only a functional but also a structural effect on the excision and maturation of the $d c$ particle.

An alternative explanation is that despite the predictions of the Campbell model, the Cys ${ }^{+}$ defective lysogens are a result of double crossover events at preferential sites between the transducing particle and the host chromosome. Lack of transduction of the met-5 marker despite the fact that att 16-3 is located closer to it than to cys-46, according to the cotransfer frequencies by the R68.45 plasmid, suggests that specific sequences might be located near to the cys-46 region, which promotes recombination at that site. 
Mating experiments were done at the Attila József University, Szeged, by one of us (L.O.) with the skilled technical assistance of Miss E. Korom. We would like to thank Dr T. Sik for his constant interest and helpful criticism. We also thank Drs T. Sik, P. Dix and I. Kiss for their critical reading of the manuscript.

\section{REFERENCES}

Arber, W. (1958). Transduction des caractéres gal par le bacteriophage lambda. Archives des sciences, Geneva 11, 259-338.

Balassa, G. (1963). Genetic transformation of Rhizobium: a review of the work of R. Balassa. Bacteriological Reviews 27, 228-241.

Beringer, J. E. \& Hopwood, D. A. (1976). Chromosomal recombination and mapping in Rhizobium leguminosarum. Nature, London 264, 291-293.

CoEtzeE, J. N. (1974). High frequency transduction of kanamycin resistance in Proteus mirabilis. Journal of General Microbiology 84, 285-296.

IuJima, T. (1966). Specialized transduction of the galactose markers by a temperate phage $\phi 170$ in Escherichia coli $\mathrm{k} 12$. Japanese Journal of Genetics 41, 121-130.

Kondorosi, A., Barabás, I., Sváb, Z., Orosz, L., Sik, T. \& Hotchkiss, R. D. (1973). Evidence for common genetic determinants of nitrogenase and nitrate reductase in Rhizobium meliloti. Nature, New Biology 246, 153-154.

Kondorosi, A., Orosz, L., SvÁB, Z. \& Sik, T. (1974). Genetic studies on Rhizobiophage 16-3. II. Helper-induced transfection. Molecular and General Genetics 132, 153-163.

Kondorosi, A., Sváb, Z., KIss, G. B. \& DrXon, R. A. $(1977 a)$. Ammonia assimilation and nitrogen fixation in Rhizobium meliloti. Molecular and General Genetics 151, 221-226.

Kondorosi, A., Kiss, G. B., Forrai, T., Vincze, E. \& BÁNFALVI, Z. (1977b). Circular linkage map of Rhizobium meliloti chromosome. Nature, London 268, 525-527.

Kowalski, M. (1967). Transduction in Rhizobium meliloti. Acta microbiologica polonica 16, 7-12.

Luria, S. E., Adams, J. N. \& Ting, R. C. (1960). Transduction of lactose-utilizing ability among strains of $E$. coli and $S$. dysenteriae and the properties of the transducing phage particles. Virology 12, 348-390.

MATSUSHIRO, A. (1963). Specialized transduction of tryptophan markers in Escherichia coli $\mathrm{K} 12$ by bacteriophage $\phi 80$. Virology 19, 475-482.

Matsushiro, A., Sato, K. \& KidA, S. (1964). Characteristics of the transducing elements of bacteriophage $\phi 80$. Virology 23, 299-306.

Meade, H. N. \& Signer, E. R. (1977). Genetic mapping of Rhizobium meliloti. Proceedings of the National Academy of Sciences of the United States of America 74, 2076-2078.

Morse, M. L., Lederberg, E. M. \& LederberG, J. (1956). Transduction in Escherichia coli $\mathrm{k} 12$. Genetics 41, 142-156.

Orosz, L. \& SIK, T. (1970). Genetic mapping of Rhizobiophage 16-3. Acta microbiologica Academiae scientiarium hungaricae 17, 185-194.

Orosz L., Sváb, Z., Kondorosi, A. \& SiK, T. (1973). Genetic studies on Rhizobiophage 16-3. I. Genes and functions on the chromosome. Molecular and General Genetics 125, 341-350.

SIK, T. \& Orosz, L. (1971). Chemistry and genetics of Rhizobium meliloti phage 16-3. Plant and Soil, special volume, 57-62.

SMITH-Keary, P. F. (1966). Restricted transduction by bacteriophage P22 in Salmonella typhimurium. Genetical Research 8, 73-82.

Sváb, Z., Orosz, L., Kondorosi, A. \& Sik, T. (1973). Study of a specially transducing Rhizobium phage. Acta microbiologica Academiae scientiarium hungaricae 20, 24.

Szende, K. \& ÖRdöGH, F. (1960). Die Lysogenie von Rhizobium meliloti. Naturwissenschaften 47, 404-405.

TAKedA, Y., Morishita, T. \& Yura, T. (1970). Specialized transduction of the galactose genes of Escherichia coli by phase $\phi 81$. Virology 41, 312355.

Wollman, E. L. (1963). Transduction spécifique du margueur biotine par le bacteriophage $\lambda$. Comptes rendus hebdomadaire des séances de l'Académie des sciences 257, 4225-4226. 